INSECTS AFFECTING DOMESTIC ANIMALS: ${ }^{1}$

" $C$ HIS work is one of the most recent of the many valuable publications on economic entomology for which we are indebted to the Department of Agriculture of the United States, and is a well-printed and well-illustrated volume of about 300 pages, giving, firstly, an enormous amount of useful information on the histories and means of prevention of insects injurious to wild and domesticated animals, and also to man. Following on this are about sixty pages devoted to the wingless parasites, classed scientifically in the sub-order Mallophaga more shortly here as "biting lice"; and a further division, of about twenty. five pages, gives under the heading of Arachnida some of the most important representatives of the "mites, ticks, scab insects, mange insects, \&c."

The value of the book is much enhanced by the excellent supply given of explanatory adjuncts, including in these a very full table of contents, with number of page bracketed to name of each insect or parasite; also an introduction dealing mainly with points of entomological classification, distribution of the pests, as to the divisions of mammals, birds, \&c., affected by them, and "Effects of Parasites on the Host, \&c."

The body of the book is followed by "A List of Parasites according to Hosts"; séveral pages with titles of works more especially bearing on the infestations previously entered on, together with the names of their authors, and a good index completes the useful volume.

In the "letter of transmittal" of the work to the U.S. Secretary of Agriculture, it is noted by Dr. L. O. Howard, Entomologist to the Department, that "the Report will form an excellent text-book of the subject, and is a work which in the opinion of the writer should be in the hands of all stock raisers." This, of course, refers primarily to stock raisers of the United States; but even on our side the Atlantic, from the plainness of the descriptions, both of infestations and remedies, the information will be of much practical use, and also as a scientific as well as practical manual should be in the hands of all our economic entomologists.

The book may be considered as in some degree a legacy, or posthumous contribution by the late Prof. Riley to the work of economic entomology, which he had so much at heart, as we are told in the "Prefatory Note" that the report was originally planned in 1885 as a conjoint work with Dr. C. V. Riley, and it is matter of congratulation that the plans have fallen in their completion into such very well-qualified hands as those of Prof. Osborn.

The accounts of the infestations consist, for the most part, of plainly-worded descriptions of the insects (suitable for general

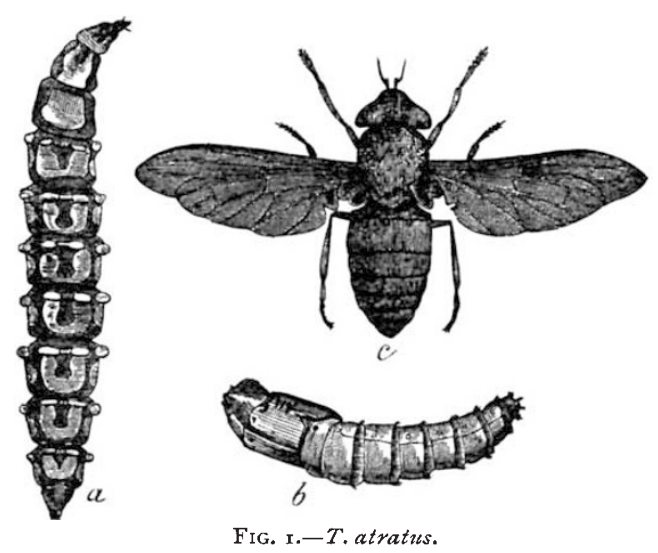

use), with notes of habits, distribution, or other points of interest, and measures of prevention and remedy. The figures are clear and good, and that at p. 61, of "The Black Gad Fly" (Tabanus atratus), after Prof. Riley, gives a good example of method of representation of the insect in all its stages (Fig. I). The

I "Insects affecting Domestic Animals : an Account of the Species of Importance in North America." By Herbert Osborn, Professor of Zoology and Entomology, lowa Agricultural College, Ames, Iowa. Bulletin No. 5 , New Series, U.S. Department of Agriculture, Div. of Entomology. (Washington: Government Printing Office, 1896.$)$

NO. I 44 I, VOL. 56] figure at p. II8, of a cow's horn with the base covered with the clustering masses of the " horn fly" (Hamatobia serrata), gives a guide to the appearance of the infestation in situ, unmistakable by the most superficial observer (Fig. 2). A single extract from

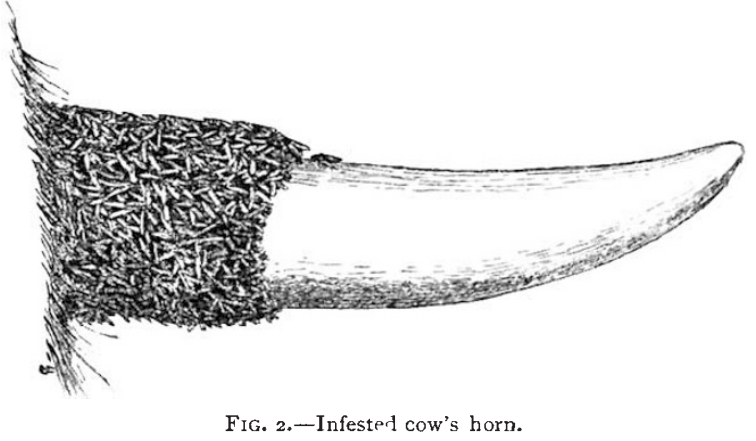

the table of contents may serve as a specimen of the completeness with which the work is given.

" Family Simulimde (black flies, buffalo gnats). Losses from buffalo gnats (p. 32)-Life-history and habits (p. 33)Preventives (p. 36)-Remedies for the bites (p. 37)-Natural enemies of buffalo gnats (p. 38)-Descriptions of species with notes on their habits (p. 38)-The Columbacz midge (p. 38)Simulium ornatum (p. 39)-The black fiy (p. 40)-The Southern buffalo gnat (p. 4I)-The Turkey gnat (p. 52)-The Western buffalo gnat (p. 55)-Simulium piscicidium (p. 56)Simulium canescens (p. 57)--Simulium rivulara (p. 57Simulium sp., in Brazil (p. 57)-Simulizm venustum (p. 57)Simulium sp., near Washington (p. 58)-Simulium pictipes (p. 58)."

E. A. O.

\section{THE ENGWURRA, OR FIRE CEREMONY OF CERTAIN CENTRAL AUSTRALIAN TRIBES. ${ }^{1}$}

A MONGST certain tribes inhabiting the centre of Australia, the last of the initiation ceremonies through which every man must pass before he is fully admitted to all the sacred mysteries of the tribe, takes the form of a series of what may be called ordeals by fire. Some such ceremony is known to us to exist amongst the Urabunna tribe, in the neighbourhood of Lake Eyre ; in the Arunta tribe, which extends across the centre of the continent to about seventy miles north of the Macdonnell Range; and also in the Ilparra and Warramunga tribes, who extend at least two hundred miles still further to the north.

We cannot fully translate the term Engwurra, or Urrumpulla, by which the rite is known in certain parts, but each of them is formed in part of the word i $r r a$, which means fire. The Arunta natives say that the ceremony has the effect of strengthening all those who pass through it. It imparts courage and wisdom, makes the men more kindly-natured, and less apt to quarrel; in short, it makes them ertwa mirra oknirra, words which respectively mean, in the Arunta tongue, "men, good, very, or great."

Evidently the main objects of it are, firstly, to bring the younger men under the control of the elders, whose commands they have implicitly to obey; secondly, to teach them habits of self-restraint and hardihood; and thirdly, to show to the younger men who have arrived at mature age, the sacred secrets of the tribe, especially those which are associated with the totems.

The Engwurra is the fourth of the initiatory rites through which every Arunta native has to pass. Of two of the three earlier ones the details have already been described by one of $\mathrm{us}^{2}{ }^{2}$ and, stated briefly, the ceremonies are as follows. At the age of about ten or twelve the boys are taken to a spot close to the main camp, where the men and women assemble. Whilst

1 The paper, of which this is an outline, was read before the Royal Society of Victoria, in April, by Prof. Baldwin Spencer and F. J. Gillen, Sub-Protector of Aborigines, Alice Springs, South Australia.

2 F. J. Gillen, in "Report on the Work of the Horn Exped. to Cent. Aust." Part iv., "Anthropology," p. ז6g. Plates $16,17,18$. 
the women dance round, the men toss the boys in the air and catch them as they fall.

This over, they are painted on the back and chest with straight or curved bands outlined by red or yellow ochre lines, the painting being done by a man who stands in the relationship to the boy of brother to a woman whom it will afterwards be lawful for him to take as wife. The boy is told that this ceremony will promote his growth, and that the time has now come when he must no longer play with, and live at the camp of, the women and children, but must go to that of the unmarried men, and live with them. He begins to accompany the men in their hunting expeditions, listens to their talks around the camp fire at night, and looks forward to the time when he shall be admitted to the privilege of manhood.

Some years elapse before the second ceremony is performed. When he arrives at puberty, or possibly not till some time later, the rite of circumcision is practised; and a short time after this, there follows the third rite-that of sub-incision. When he has passed through these three ceremonies, the native is admitted to the ranks of the men; he may wear a hair girdle round his waist, tie his hair back with the forehead-band, and may take a wife.

The different periods of his life are indicated by different terms. When a mere child, he is Amba-querka ; after having been thrown up, he is Ulpmerka; after circumcision, he is Arrakurta ; after sub-incision, he is Ertwa-kurka ; and finally, when he has passed through the Engwurra, he becomes an Urliara.

The Engwurra ceremony, which the authors witnessed, was held amongst the Macdonnell Ranges, in the vicinity of Alice Springs telegraph station on the overland telegraph line between Adelaide and Port Darwin. Of this station one of the authors is officer in charge; and his long acquaintance with the natives, as well as the fact that he is Sub-Protector of the Aborigines, has given him special facilities for gaining their confidence.

The ceremony lasted four months, commencing in September 1896, and ending in January I897; and during this period the authors spent the greater part of the time in the native camp, being allowed to witness everything which took place-being, in fact, regarded as members of the tribe.

The spot chosen for the ceremony was a level stretch of ground, hemmed in on one side by a range of rugged quartzite, and on the other by the River Todd, which, like all other Central Australian rivers, is, except at rare intervals, a dry tract of sand bordered by steep banks on which grows a fringe of gumtrees and low scrub. This level flat formed the Mirra Engwurra, or Engwurra Camp. The women's camp was out of sight on the other side of the river; for, needless to say, the women and uninitiated were not allowed to go anywhere near to the sacred ground.

The natives are summoned to the Engwurra by messengers sent out by the old man who presides at the ceremony. There may be one or more messengers, and each carries one or two of the sacred sticks or Churinga wrapped up from sight in emu feathers, the Churinga being of the nature of the objects commonly called bull-roarers. The messenger who summons to the Engwurra is called Ilchinkinja, the word being a compound of ilcha, hand, and inkinja, to lift up, and may be translated by the term "the beckoning hand." The significance of the Churinga will be seen shortly; meanwhile it may be said that in their natural state no native dare disobey such a summons, through fear of the harmful consequences which would befall him if he did so.

Representatives of the different local groups of the Arunta tribe assembled early in September, each group bringing with it stores of its sacred Churinga, which were under the careful charge of the elder men.

Before going further, it is necessary to allude briefly to the organisation of the tribe. Its division into exogamously intermarrying phratries or classes has been already clearly shown by Messrs. Howitt and Fison, and later by Messrs. Gillen and Stirling. There is little doubt but that originally there were two main phratries, each of which became divided again into two, whilst at the present day the division has been, or rather is now being, carried still further, with the result that instead of four, we have eight sub-phratries. This division into eight exists in reality throughout the tribe; but it is only amongst the northern groups that there are separate names for each of them, and it will be simpler here to deal with the four which are found throughout the tribe. The names of these four are Panunga,
Bultharra, Purula and Kumarra. One moiety of the tribe consists of the first two, the other of the second two. The marriage arrangements are as follows :-

fBultharra (male) marries Kumarra, children are Panunga.
Panung
Purula,
Kumarra
Panunga,
, Bultharra.
," ", Bultharra, ", "Kumarra.

Every Bultharra man, for example, must marry a Kumarra woman, that is, one who comes from the moiety of the tribe to which he does not belong, and their children, go into the man's moiety, but into the sub-phratry to which he did not belong. At the same time the Kumarra women are divided into two sets, owing to the social organisation-details of which will subsequently be published by the authors-and these two sets stand respectively to each individual Bultharra man in the relationship of what is called Unawa and Unkulla, and it is only the former who are eligible to him as wives. In just the same way the Bultharra men are divided into two sets, who stand respectively to any Kumarra woman in the relationship of Unawa, whom she may marry, and Unkulla, whom she may not.

There can be no doubt whatever about the fact that the Panunga and Bultharra form one moiety, and the Kumarra and Purula another. This is shown in various ways, and when large numbers of the natives are gathered together at such a ceremony as the Engwurra, it stands out most clearly. Not only are there two main camps on the Engwurra ground, at one of which the Panunga and Bultharra gather, and at the other the Purula and Kumarra, but the sacred Churinga are deposited in two separate spots, those of the Panunga and Bultharra being placed, during the Engwurra which the authors witnessed, on a platform erected in a Mulga tree on the hill-side, overlooking at one end the ceremony ground, whilst those of the Kumarra and Purula were placed on a small platform at the opposite end.

As soon as the natives had begun to assemble, the Alice Springs blacks, in whose locality the ceremony was to be performed, opened the proceedings by performing two corrobborees, or ordinary dancing festivals, which occupied the evenings of the first three weeks, and at which, as they are not sacred, the women are allowed to be present, and to take part.

Before these were finished, the old man presiding over the Engwurra went to the chosen ground, and there raised a small mound of earth about forty feet long, one foot high, and two feet across, planting all along it small boughs of Eucalyptus. This mound is called the Parra, and apparently represents a tract of country. When this was done, the older men, who had already passed through the ceremony, and had thus become Urliara, together with the younger men, about forty in number, and varying in age from twenty to thirty-five, or even forty, who were to be made Urliara, spent the whole time during the ensuing two and a half months in the performance of sacred ceremonies on the Engwurra ground. Every day a certain number of young men are sent out to hunt for game, but from this time forward until the end of the whole ceremony they are not supposed to go near the women's camps. They must sleep at night on the Engwurra ground, and are completely under the control of the older men, whose orders they must implicitly obey.

The sacred ${ }^{1}$ ceremonies, of which the authors witnessed the performance of about sixty, were all concerned with the numerous totems into which the members of the tribe are divided, and the special object of the authors was to gain an insight into the totemic system, and in connection with this to arrive, if possible, at a correct knowledge of the significance of the Churinga. These Churinga; or sacred sticks and stones, ${ }^{2}$ are the most valuable possession of the Arunta natives, and throughout the tribe they are stored in considerable numbers in special hidingplaces, the exact locality of which is only supposed to be known to the older men of each local group in whose district they are preserved. The whole tribe is divided up into a large number of such local groups, who reside in and are regarded as the proprietors of a definite tract of land, and each of the latter is especially associated with the name of some object, which is usually that of an animal or plant, and is, in fact, the totem of

1 The term sacred is used to distinguish them from the ordinary ones, such as the dancing testivals, commonly called corrobborees, which any one women and children included, may witness, whilst the sacred ones may only be seen by initiated men.

2 Remarks tupon and drawings of some of these will be found in the work by Messrs. Gillen and Stirling, previously alluded to. Therein Mr. Gillen supplied the information that they were symbolic of the totems, which may be modified now by saying that each Churinga is symbolic of an individual belonging to a particular totem.

NO. I 44 I, VOL. 567 
the majority of individuals who occupy that particular area. The whole country occupied by the Arunta--and the same is true of other tribes of which the authors have information-is divided up into a large number of parts, each comprising what the natives call an Oknannikilla, which may be described as a local totem centre. There are, for example, certain areas forming wild cat oknannikillas, others emu, kangaroo, mulga, frog, and so on, the exact position of which is known to the natives.

If, on the other hand, we examine the Urabunna tribe, which adjoins the Arunta on the south, we see clearly a fundamental difference in regard to the totemic system. The Urabunna are divided into two phratries, viz. Matthurrie and Kirarawa, and each of these again into certain totems, the same totem not occurring in both phratries. The organisation of the tribe is such that a Matthurrie man must marry a Kirarawa woman, and not only this, but there is the further restriction that a man of one totem must marry a woman of another. Thus a Matthurrie cricket man must marry a Kirarawa crow woman, and, as descent is counted through the mother, and not, as in the Arunta, through the fatner, the children are Kirarawa and crows.

In the Arunta it is quite different, and so far as the totems are concerned, at first sight most perplexing. The subphratry name is simple, every child of a Bultharra man and a Purula woman is a Panunga, and so forth, but there is no such orderly method in the totem names. The following actual examples of three, amongst many families investigated by the authors, are typical of what is found through the tribe.

In the first family the father is Hawk; wife No. I, Bandicoot; daughter, Witchetty Grub ; wife No. 2, Kangaroo ; no children; wife No. 3, Lizard ; two daughters, one Emu, the other Water.

In the second family the father is Witchetty Grub; wife No. I, Lizard ; no children; wife No. 2, Munyeru (grass seed); two daughters, one Lizard, the other Witchetty Grub.

In the third family the father is Eaglehawk; wife No. I, Hakea flower; no children; wife No. 2, Hakea flower; three sons, respectively Witchetty Grub, Emu, Eaglehawk; two daughters, each Witchetty Grub.

Two things are clear, first, that the totems, as they now exist, have nothing to do with regulating marriage; and second, that the totems of the children do not of necessity follow either that of father or mother; they may be identical with either or both of them, or they may be entirely different.

It was whilst watching the ceremonies during the Engwurra, and questioning carefully the performers after each one was concluded, that the authors were able to gather information explaining this apparently perplexing system, and also to arrive at an understanding of the significance of the Churinga. The information derived is briefly as follows.

Each ceremony was connected with some particular totem and, further, with some special locality, and each one dealt with some particular ancestral individual or individuals. The traditions of the tribe refer back to a long past time called the Alcheringa (which means dream-times), when their ancestors were designated by the name of, usually, some animal or plant. Thus we have a group of individuals living in the Alcheringa, of whom it is difficult to say whether they were men-kangaroos or kangaroo-men, the identity of the human individual being sunk in that of the object with which he is associated, whose name he bears, and from whom he sprung. These kangaroo-men walked about the country now inhabited by the tribe, following a definite route and halting at certain places, the positions of which are well known to the natives by means of the traditions which have been handed down from generation to generation. In a similar way groups of Emu, Frog, Mulga, Wild Cat, and other individuals walked across the country.

Each one of these Alcheringa ancestors carried with him or her a number of sacred Churinga, and where they halted, there an oknannikilla or local totem centre was formed. At each spot, so says tradition, certain individuals went into the ground, and each became a Churinga, which is associated with the spirit part of the individual. Not only this, but at each such spot they deposited a large number of the Churinga which they carried, and with each one of which in the same way a spirit individual was associated.

Then the whole area now occupied by the tribe became, as it were, dotted over with a large number of local totem centres, and this idea of spirit individuals of definite totems, associated with Churinga and resident in certain spots, lies at the root of the present totemic system of the Arunta and other tribes of Central Australia.

NO. I 44 I, VOL. 567
Thus we have close to Alice Springs a large and important Witchetty Grub totem centre, and the following will serve as a typical example of how each man and woman gain a totem name. There were deposited in the Alcheringa, close by Alice Springs, a large number of Witchetty Churinga, each of course associated with a spirit individual. The latter can move about, and always carries with it its Churinga, and is supposed to frequent some special tree or stone, which is called its Nanja tree or stone. When a woman conceives, it is one of these spirit individuals who has entered her body, and therefore, quite irrespective of what the father or mother's totem may be, the child when born must of necessity belong to the spot at which it was conceived, or rather at which the mother believes that it was. Recently, for example, an Emu woman from another locality came on a visit to Alice Springs. There she conceived a child, but returned to her own Emu locality before that child vas born. When born, that child was a Witchetty Grub-it must be, the natives say, because it entered the mother's body at Alice Springs, which is a Witchetty totem centre ; it is, in fact, nothing more nor less than the reincarnation of an Alcheringa Witchetty Grub. Had it entered the mother within the limits of her own Emu locality, it would as inevitably have been born an Emu

Further, when the spirit-child enters the mother, it drops its Churinga. After it is born the mother tells the father exactly where it was conceived - that is, the spot where she first became aware that she bad conceived a child-and the father and one or two other men go there, and either search until they find the Churinga, or if they do not find one, then they make one out of the mulga or other hard wood tree which lies nearest to the Nanja tree, carve on it the design of the child's totem, and hand it over for safe keeping to the head man of that locality, who places it in the sacred storehouse where all the Churinga of that totem centre are preserved. This Churinga becomes the Churinga Nanja of the child.

The meaning and importance of the Churinga may be gathered from the above sketch, from which many details, to be published later, are of necessity omitted.

It is during the Engwurra, and whilst the ceremonies concerned with the totems are being performed, that the old men of the tribe show the Churinga to the younger men, telling them to whom they have belonged and the traditions associated with them, and thus ensure the passing on of this knowledge from generation to generation; in fact, in ceremonies such as these we see the earliest beginnings of historical records.

Whilst the Engwurra is largely concerned with the performance of the sacred ceremonies, an equally important part is played by the fire ordeals from which the name is derived, and to which reference must now be briefly made. A full description of these, together with illustrations from photographs taken by the authors, will be published as soon as possible.

During the last month of the time occupied by the performance of the Engwurra the young men, who are being made Uriara, are taken out into the bush every day before sunrise, under the charge of certain elder men. There they have to remain all day hunting game, which must be brought in to the elder men, who stay in camp performing ceremonies. The young men are not supposed to eat much, and become poorer and poorer as the weeks pass by. Usually, but not always, they are brought back to the Engwurra ground by way of the women's camp. Just before sunset the women-Bultharra and Panunga in one spot, and Purula and Kumarra in another, some little distance apart-make a fire of bushes, and, standing behind this, move their hands as if inviting the young men, who are now called Illpongwurra, to approach. This they do, holding shields and boughs of a particular shrub over their heads. Then the lubras or women, carrying burning grass and boughs, run towards them, and throw the burning material over their heads. The men have to protect themselves with shields as well as they can, and after going to each fire they turn tail, followed by the women, who stop and run back again when they reach the bed of the river, on the other side of which lies the Engwurra ground, which they must not approach. Arrived at the latter, the young men lie down in a long row, each man having his head upon the Parra. Perfect silence is maintained, and here they must remain until the old men give them permission to arise. Each old man takes charge of four or five young men, who become what is called apmurra to him and he to them, and no young man may speak to, or in the presence of, his apmüra till all is over. 
Within the last week of the ceremony the young men have to undergo another and more severe ordeal. In a secluded spot amongst the hills the old men, who have gone cut in charge of them, make a large fire of logs. When these have burned down, and the red-hot ashes remain, green boughs of Eucalyptus are thrown on the fire, and on these the young men have to lie down in the heat and stifling smoke until they receive permission from the old men to get up.

Finally, on the last night the $\mathrm{me}_{\mathrm{x}_{x}}$ all congregate around a sacred pole which has been erected close by the Parra, and here, all night long, the old men decorate the backs and chests of the younger men with designs, often very elaborate and distinctive, of the various totems. A man is not of necessity-in fact, very seldom is-painted with the design of his own totem. All night long the women remain awake and active in their camp across the river, where again they make two fires in shallow pits, but this time closely side by side.

Before sunrise the decorated men gather together at the base of the sacred pole, "the head man of the ceremony .breaks through the Parra mound, and across the opening thus formed the old men lead their charges, all walking in single file and holding one another's hands. In perfect silence the string of painted men pass from the Engwurra ground across the bed of the creek, and so on to the women's camp, where they form a group, and halt some fifty yards away from the women, who stard behind their fires, which are now giving off dense clouds of smoke from green gum boughs.

Then each old man takes the younger ones under his charge, and with them runs up to the fires. The Bultharra and Panunga men go to the fire made by the Purula and Kumarra women, and vice vers $\hat{a}$, kneeling upon it while the women press them down with their hands upon the men's shoulders. When all have been upon the fires, the old men and the newly-made Urliara cross the river-bed again to the Engwurra ground, and sit around the sacred pole. The fire ceremonies are now complete, but as yet the younger men may not speak to their apmuirra, but must remain out in the bush. After a length of time, varying from two weeks to perhaps six months, each young man brings in a present of food called Chowarilya to his apmürra man, when a sacred ceremony is performed, at the close of which the mouths of the old and young men who are present are touched either with the food brought in, or with some object which has been used in the ceremony, and the ban of silence is removed.

\section{PROFESSOR NEWCOMB ON THE DISTANCES OF THE STARS.}

THE problem of the distances of the stars is of peculiar interest in connection with the Copernican system. The greatest objection to this system, which must have been more clearly seen by astronomers themselves than by any others, was found in the absence of any apparent parallax of the stars. If the earth performed such in immeasurable circle around the sun as Copernicus maintained, then, as it passed from side to side of its orbit, the stars outside the solar system must appear to have a corresponding motion in the other direction, and thus to swing back and forth as the earth moved in one and the other direction. The fact that not the slightest swing of that sort could be seen was, from the time of Ptolemy, the basis on which the doctrine of the earth's immobility rested. The difficulty was simply ignored by Copernicus and his immediate successors.

An indication of the extent to which the difficulty thus arising was felt is seen in the title of a book published by Horrebow, the Danish astronomer, some two centuries ago. This. in. dustrious observer, one of the first who used an instrument resembling our meridian transit of the present day, determined to see if he could find the parallax of the stars by observing the intervals at which a pair of stars in opposite quarters of the heavens crossed his meridian at opposite seasons of the year. When, as he thought, he had won success, he published his observations and conclusions under the title of "Copernicus Triumphans." But, alas! the keen criticism of his contemporaries showed that what he supposed to be a swing of the stars from season to season arose from a minute variation in the rate of his clock, due to the different temperatures to which it was exposed during the day and the night. The measurement of the distance

1 Extracted from an address given by Prof. Simon Newcomb at the dedication of the Flower Observatory, University of Pennsylvania, May 12 . even of the nearest stars evaded astronomical research, until Bessel and Struve arose in the early part of the present century.

On some aspects of the problem of the extent of the universe light is being thrown even now. Evidence is gradually accumulating which points to the probability that the successive orders of smaller and smaller stars, which our continually increasing telescopic power brings into view, are not situated at greater and greater distances, but that we actually see the boundary of our universe. This indication lends a peculiar interest to various questions growing out of the motions of the stars. Quite possibly the problem of these motions will be the great one of the future astronomer. Even now it suggests thoughts and questions of the most far-reaching character.

I have seldom felt a more delicious sense of repose than when crossing the ocean during the summer months I sought a place where I could lie alone on the deck, look up at the constellations, with Lyra near the zenith, and, while listening to the clank of the engine, try to calculate the hundreds of millions of years which would be required by our ship to reach the star a Lyræ if she could continue her course in that direction without ever stopping. It is a striking example of how easily we may fail to realise our knowledge when I say that I have thought many a time how deliciously one might pass those hundred millions of years in a journey to the star $a$ Lyræ, without its occurring to me that we are actually making that very journey at a speed compared with which the motion of a stearnship is slow indeed. Through every year, every hour, every minute, of human history from the first appearance of man on the earth, from the era of the builders of the Pyramids, through the times of Cæsar and Hannibal, through the period of every event that history records, not merely our earth, but the sun and the whole solar system with it, have been speeding their way towards the star of which I speak on a journey of which we know neither the beginning nor the end. During every clock-beat through which humanity has existed it has moved on this journey by an amount which we cannot specify more exactly than to say that it is probably between five and nine miles per second. We are at this moment thousands of miles nearer to $a$ Lyræ than we were a few minutes ago when I began this discourse, and through every future moment, for untold thousands of years to come, the earth and all there is on it will be nearer to $\alpha$ Lyre, or nearer to the place where that star now is, by hundreds of miles for every minute of time come and gone. When shall we get there? Probably in less than a million years, perhaps in half a million. We cannot tell exactly, but get there we must if the laws of nature and the laws of motion continue as they are. To attain to the stars was the seemingly vain wish of the philosopher, but the whole human race is, in a certain sense, realising this wish as rapidly as a speed of six or eight miles a second can bring it about.

I have called attention to this motion because it may, in the not distant future, afford the means of approximating to a solution of the problem already mentioned, that of the extent of the universe. Notwithstanding the success of astronomers during the present century in measuring the parallax of a number of stars, the most recent investigations show that there are very few, perhaps hardly more than a score of stars of which the parallax, and therefore the distance, has been determined with any approach to certainty. Many parallaxes, determined by observers about the middle of the century, have had to disappear before the powerful tests applied by measures with the heliometer; others have been greatly reduced, and the distances of the stars increased in proportion. So far as measurement goes, we can only say of the distances of all the stars, except the few whose parallaxes have been determined, that they are immeasurable. The radius of the earth's orbit, a line more than ninety millions of miles in length, not only vanishes from sight before we reach the distance of the great mass of stars, but be. comes such a mere point that, when magnified by the powerful instruments of modern times, the most delicate appliances fail to make it measurable. Here the solar motion comes to our help. This motion, by which, as I have said, we are carried unceasingly through space, is made evident by a motion of most of the stars in the opposite direction, just as, passing through a country on a railway, we see the houses on the right and on the left being left behind us. It is clear enough that the apparent motion will be more rapid the nearer the object. We may, therefore, form some idea of the distance of the stars when we know the amount of the motion. It is found 